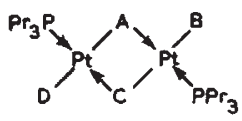

(I)

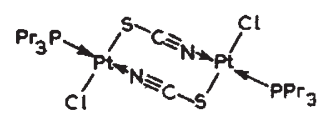

(III)

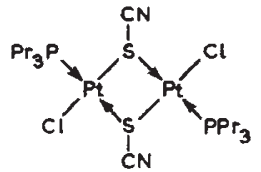

(II)

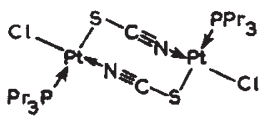

(IV) the thiocyanate bridge is formed through both the sulphur and nitrogen atoms. We have therefore examined its infra-red spectrum and find that the SCN stretching vibration frequency $\left(2,149 \mathrm{~cm} .^{-1}\right)$ is closely similar to those observed in our isomers $\left(\alpha, 2,162 \mathrm{~cm}^{-1} ; \beta, 2,169 \mathrm{~cm}^{-1}\right)$. This supports the possibility of bridging by $\mathrm{Pt}-\mathrm{S}-\mathrm{C} \equiv \mathrm{N} \rightarrow \mathrm{Pt}$ in our isomers, and if they have structures (II) and (III) we might expect (III) to be the unstable $\alpha$-isomer.

We have now examined the structure of the $\alpha$ isomer by $\mathrm{X}$-rays and do indeed find that it has structure (III). Until we know the structure of the $\beta$-isomer, which is now under investigation, the exact nature of the isomerism is uncertain, but it is not a geometrical isomerism of the type previously proposed ${ }^{2}$.

We have sought this type of isomerism in other similar complexes and find that the tetrathiocyanate (I ; $A=B=C=D=\mathrm{SCN}$ ) also exists in two isomeric forms. In this case the unstable form is too labile to be isolated in a pure condition.

Full details will be published elsewhere.

$$
\begin{aligned}
& \text { J. Chatt } \\
& \text { L. A. Duncanson } \\
& \text { F. A. Hart } \\
& \text { P. G. OWston }
\end{aligned}
$$

Imperial Chemical Industries Limited,

Akers Research Laboratories,

The Frythe,

Welwyn, Herts.

$$
\text { Oct. } 11 .
$$

1 Chatt, J., and Hart, F. A., Nature, 169, 673 (1952).

"Chatt, J., and Duncanson, L. A., Nature, 178, 997 (1956).

Isindqvist, I., Acta Cryst., 10, 29 (1957).

\section{A New Superstructure in Gamma-Ferric Oxide}

Since 1935 it has been generally accepted that gamma-ferric oxide has the structure of magnetite (spinel structure) with cation vacancies'. The vacancies were assumed to be randomly distributed on all octahedral iron sites of magnetite. Magnetite contains 8 molecules of $\mathrm{Fe}_{3} \mathrm{O}_{4}$ in the face-centred cubic unit cell and has the space group $F d 3 m$. Gamma-ferric oxide contains 102 molecules of $\mathrm{Fe}_{2} \mathrm{O}_{3}$ in the unit cell. Due to the occurrence of a number of extra reflexions in the X-ray diagram of gammaferric oxide also occurring in the diagram of ordered lithium ferrite $\mathrm{Fe}_{8}\left[\mathrm{Li}_{4} \mathrm{Fe}_{12}\right] \mathrm{O}_{32}$, and to the fact that the material he used contained some water, P. B. Braun $^{2}$ of this Laboratory suggested that in these gamma-ferric oxide specimens the same super- structure occurs as in ordered lithium ferrite. The ideal composition for ordering would be $\mathrm{Fe}_{8}\left[\mathrm{H}_{4} \mathrm{Fe}_{12}\right] \mathrm{O}_{32}$. For compositions between $\mathrm{Fe}_{8}\left[\mathrm{H}_{4} \mathrm{Fe}_{12}\right] \mathrm{O}_{32}$ and $\mathrm{Fe}_{8}\left[\left(\mathrm{Fe}_{11} \mathrm{C}_{28}\right) \mathrm{F}_{\theta_{12}}\right] \mathrm{O}_{32}$ the same superstructure reflexions were observed. (The square brackets [ ] denote the cations on octahedral sites, the ordinary brackets ( ) those on the Li-sites in ordered $\mathrm{LiFe}_{8} \mathrm{O}_{8}$.)

If the $1 \frac{1}{3} \mathrm{Fe}$-atoms and the $2 \frac{2}{3}$ vacancies are randomly distributed on the positions of the four lithium atoms in ordered lithium ferrite the space group of gamma-ferric oxide would be the same as that of ordered lithium ferrite, namely, $P 4_{1} 3$ (or $P 4_{3} 3$ ). This is a sub-group of $F d 3 m$. The extra reflexions found by Braun are compatible with a primitive cubic unit cell, but not with the face-centred cubic cell of spinel.

In the $\mathrm{X}$-ray diagrams of a number of commercial samples of gamma-ferric oxide of different origin and in the diagrams of a number of our own preparations we have found a faint reflexion between $\Sigma h^{2}=6$ and $\Sigma h^{2}=8$. In order to be certsin that this reflexion is not caused by an impurity we prepared ${ }^{3}$ gamma-ferric oxide by decomposing very pure ferrous oxalate dihydrate in an atmosphere of steam and nitrogen followed by oxidation with a mixture of nitrogen and air at $250^{\circ} \mathrm{C}$. The water content is less than one-half weight per cent.

In the X-ray diagram made of this material on a 'Norelco' diffractometer with cobalt $K_{\alpha}$ radiation, even the strongest reflexion of alpha-iron oxide could not be detected. Beside the superstructure reflexions found by Braun, the reflexion between $\Sigma h^{2}=6$ and $\Sigma h^{2}=8$ mentioned above and fourteen others between $12^{\circ}$ and $46^{\circ}(2 \theta)$ have been found.

It has been possible to assign indices to all the reflexions using a tetragonal unit cell having $c / a=3$ and $a_{0}=8.33 \mathrm{~A}$. Absence of the reflexions $00 l$ with $l \neq 4 n$ points to a fourfold screw axis with a translation of $1 c$. There are no indications of a non-primitive unit cell.

On the assumption that the structure is still practically that of spinel, the new unit cell must contain 32 molecules of $\mathrm{Fe}_{2} \mathrm{O}_{3}$, and the space group is $P 4_{1}$ (or $P 4_{3}$ ). This is a subgroup of $P 4_{1} 3$.

The position of the $3 \times 1 \frac{1}{3}=4$ iron atoms and the $3 \times 2 z_{3}^{2}=8$ vacancies distributed on the $3 \times 4=12$ lithium sites is determined by the fourfold screw axis. (Iron at $4 a: \quad x, y, z ; \quad \bar{x}, \vec{y}, \frac{1}{2}+z ; \bar{y}, x, \frac{1}{4}+z ; y, \bar{x}, \frac{3}{4}$ $+z$.) A verification of the proposed structure by calculation of the intensities is in progress and will be published in detail.

In the course of the present work a paper by R. Collongues came to our attention. He found a number of superstructure lines compatible with a tetragonal unit cell with $c / a=2$. The discrepancy between his and our results is due to the fact that he has observed a smaller number of extra reflexions and because his samples contain alpha-ferric oxide.

\section{G. W. VAN OOSTERHOUT \\ C. J. M. ROOIJMANS}

Philips Research Laboratories,

N.V. Philips' Gloeilampenfabrieken, Eindhoven. June 28.

${ }^{1}$ Verwey, E. J. W., Z. Krist., A, 91, 65 (1935). Hägg, G., Z. phys. Chem., B, 29, 88 (1935). Kordes, E., Z. Krist., A, 91, 193 (1935). ${ }^{2}$ Braun, P. B., Nature, 170, 1123 (1952).

3 British Patent 688903.

4 Collongues, R., thesis (Paris, 1957). 